ganized group, then presumably the group too should be subject to some form of regulation. Control over organized groups may be effected in either of two ways. Legislation may be enacted to encourage the dissolution of the group by imposing criminal sanctions on persons who organize or join an outlawed society. While this technique may be expedient from the point of view of swift and certain results, when applied to organized social and political societies, it may operate with an indiscriminate and altogether dangerous severity. Corporate action and the propensity to combine is as fully characteristic of modern social and political behavior as of economic. ${ }^{74}$ Although freedom of association is not expressly protected by the Constitution, the right of free speech and other basic civil rights would be seriously jeopardized if individuals were severely restricted in organizing and joining associations to promote their views..$^{75}$

A second, and perhaps more feasible, method by which to effect control over organized societies would be to impose sanctions on members who themselves engage in criminal activity. The area of membership liability should be the same as that outlined by the rules set out in the Federal Criminal Code. ${ }^{76} \mathrm{It}$ would be a serious error, however, to attempt to effect this control by assigning criminality to any fictitious group entity. Persons tried for criminal acts committed through the medium of organized associations should be afforded the safeguards of the traditional criminal trial.

\title{
POST-KINSEY: VOLUNTARY SEX RELATIONS AS CRIMINAL OFFENSES
}

The recent publication of the Kinsey Report, ${ }^{1}$ the first in a series of studies which will eventually include an entire volume devoted to legal aspects of sex behavior, presents a rare opportunity for re-examining a portion of the criminal law in the light of a factual study of the relevant social behavior. Professor Kinsey and his associates have made a taxonomic investigation of the external sex expression of some 5,300 representative white American males, and the authors' careful methods of sampling ${ }^{2}$ permit, within limits pointed out by responsible critics, ${ }^{3}$ extension of the findings to the whole sampled group.

74 See Wyzanski, The Open Window and the Open Door, 35 Calif. L. Rev. 336 (I947).

${ }^{75}$ Bowe v. Sec'y of the Commonwealth, 320 Mass. 230,69 N.E. 2 d II5, I30 (I946). It would seem appropriate, therefore, to apply the clear-and-present-danger test to legislative restraints on organizing and joining. Shaw v. State, 76 OkJa. Cr. 27I, I34 P. 2 d 999 (I943). In curbing the exercise of constitutionally protected rights, legislation must not be so broad as to comprehend conduct which in all other respects is wholly lawful; see Thornhill v. Alabama, 3 I0 U.S. 88 (1940).

${ }^{76}$ See note 17 supra.

${ }^{1}$ Kinsey, Pomeroy, and Martin, Sexual Behavior in the Human Male (I948).

2 Ibid., at 82-109.

3 Goldstein and Pastore, 26 J. of Psychology 347 (1948); Riley, Some Observations on the Sampling Methods Used in the Report, in Problems of Sexual Behavior 37 (I948). For good 
Objections to the Report's failure to investigate psychological data 4 which would explain motivations for sex expression do not indicate an omission which detracts from the work's usefulness here, because the laws to be scrutinized deal only with external manifestations of individual behavior without inquiring into their psychological causes. ${ }^{5}$

Notwithstanding the arousal of new popular interest in the status of our sex law by the wide lay circulation of the Report and its sensational allegation that 95 per cent of all males engage in sexual activities punishable as crimes, there has not been extensive comment from the legal profession. ${ }^{6}$ This apathy may reflect an attitude that Kinsey merely underscores the obvious, or a feeling that while the need for a reevaluation of some of the premises underlying sex law may be granted, any attempt to change the status quo would be doomed to failure. Lay skeptics, however, may interpret silence as a tacit admission of Kinsey's serious charges that lawyers and judges seek to impose their own class standards of sex behavior upon the rest of the community. ${ }^{7}$ Popular discontent with the "arbitrary and backward nature" of a substantial segment of the criminal law, perhaps now strengthened by the Report, may foster the spreading of an attitude of disrespect for other laws felt to be equally arbitrary and thus create grave enforcement problems.

The concept of "sex crime" popularly conveys the idea of reprehensible acts such as forcible rape or attacks upon small children. Few persons realize the extent to which voluntary private sex relations between adults are also beyond the law. While private voluntary sex acts, except for sodomy ${ }^{8}$ and indecent ex-

overall reviews of the Report not specifically concerned with sampling methods, see $3^{\text {I Sat }}$ Rev. of Lit. I7 (March I3, I948); Gorer, I7 Am. Scholar 280 (1948); Trilling, I5 Partisan Rev 460 (1948).

1 Benedict, 3 I Sat. Rev. of Lit. 34 (March I3, I948); Eisenbud, A Psychiatrist Looks at the Report, in Problems of Sexual Behavior 58 (1948); Mead, An Anthropologist Looks at the Report, ibid., at 20.

${ }^{5}$ Sex laws and the Kinsey Report are alike in that they both fail to take into account the motivating forces which find overt expression in the illicit sex act. Sex laws, of course, have been criticized along with many other criminal laws for failing to differentiate between various causal inducements to commit an offense, distinctions which are important in determining the best means towards reformation of the offender. Glueck, Sex Crimes and the Law, 45 Nation 3 I8 (1937). Fortunately the question of mens rea, which might also necessitate an inquiry in to the omitted data, is of almost no importance in sex offenses where regularly the act without more is punishable.

- But see review comments by Burling, 23 N.Y.U.L.Q. Rev. 540 (I948); Ernst, 3 I Sat. Rev. of Lit. I9 (March I3, I948); Holcomb, 38 J. Crim. L. 687 (1948); Letourneau, 26 Can. Bar Rev. 746 (I948); Schwartz, g6 U. of Pa. L. Rev. 9I4 (I948). See also Harper, Legal Considerations in Relation to the Report, in Problems of Sexual Behavior 47 (1948); Llewllyn, The Limits of Sexual Law, in About the Kinsey Report Ir3 (ed. Geddes and Currie r948); Ploskowe, Sexual Patterns and the Law, in Sex Habits of American Men I25 (ed. Deutsch 1948); Ernst and Loth, American Sexual Behavior and the Kinsey Report 124-4I (I948).

7 Kinsey, op. cit. supra note $I$, at 389-93.

${ }^{8}$ At common law sodomy, confined to acts per anum or with beasts, was punishable as a capital felony. $4 \mathrm{Bl}$. Comm. ${ }^{* 15}$. 
posure, ${ }^{9}$ were not punishable under the common law of England, they were subject to the jurisdiction of the ecclesiastical courts. ${ }^{10}$ The early American colonists, insisting on strict enforcement of the Puritan version of scriptural law and therefore not satisfied with the sparse sanctions of the common law, enacted special statutes punishing virtually all nonmarital sex activity. ${ }^{11}$ Their descendants sought to enact similar laws in the territories and states successively settled by them, but different local conditions and the time lag between successive enactments made for little uniformity in the provisions of these statutes. ${ }^{12}$

sintwit

This note will appraise the status and administration of those statutes which are applicable to voluntary sex acts between adults in the light of the Kinsey statistics. These acts, numerically the most significant, occupy a unique position in American jurisprudence.

\section{I}

It is necessary at the outset to establish the states and population percentages covered by different classes of sex laws, and to ascertain that portion of the white male adult population which would be subject to prosecution under these laws at any given time. The offenses selected for consideration are coextensive with the category "other sex offenses" as defined by state and federal criminal statistics. This group includes adultery, fornication, incest, ${ }^{13}$ indecent exposure, ${ }^{14}$ lewdness, seduction, ${ }^{15}$ and sodomy, but excludes rape, commercialized vice, and offenses against family and children, which form separate statistical groups. As this study has been further restricted to voluntary private sex acts between adults which occur often enough to be statistically relevant, incest, indecent exposure, and seduction have also been excluded, thus leaving only adultery, ${ }^{16}$ fornication, lewdness and sodomy ${ }^{17}$ laws for the tabulation below. ${ }^{18}$

- Rex v. Crunden, 2 Camp. 89 (I809), citing Rex v. Sedley, I Keb. 620, 2 Sid. I68 (I664).

${ }^{10} \mathrm{But}$ the ecclesiastical courts lost their powers in the 17 th century. $4 \mathrm{Bl}$. Comm.*64; May, Social Control of Sex Expression 200 (1936). Occasionally, penalties for fornication were imposed by the manorial hall-moots. 2 Pollock and Maitland, History of English Law 543 (2d ed. 1899 ).

11 May, op. cit. supra note 9 , at $232-56$.

${ }^{32}$ An example of this development is indicated by Ohlson, Adultery: A Review, r7 B.U.L. Rev. 328,532 (1937).

${ }^{13}$ Kinsey furnishes no data on incest but regards its incidence as very low. Kinsey, op. cit. supra note $I$, at 558 .

${ }^{4}$ Indecent exposure, a misdemeanor in nearly all states, is not a relation but is usually defined as an exhibition in public of nudity or a sex organ by an individual.

${ }^{15}$ Seduction presupposes deceit on the part of the seducer (usually in the nature of a fradulently given promise to marry) and hence cannot be classified as "voluntary." Del., Fla., Kan., La., Me., Nev., Tenn., Utah, Vt., and W. Va. do not make seduction a crime in addition to allowing redress in a civil action.

${ }^{16}$ The jurisdictions disagree as to who may be punished as an adulterer. Some hold that the offense can only be committed by a married person, while others hold both parties where one of them is married, and still others, following the Roman law, require one of the participants to be a married woman. See 2 Wharton, Criminal Law $\$ \$ 2079-84$ (I2th ed. I932). 
Some of the factual prerequisites required to invoke a given statute are listed under "qualifications" in the table. The distinctions, however, have not been drawn too finely. For example, the phrase "open and notorious," which is subject to different interpretations, has been construed not to require publicity;

${ }^{17}$ Sodomy, which in most statutes is not specifically defined and thus embraces the common-law definition, has elsewhere been enlarged to include passive and active mouth-genital activities and attacks on dead bodies, and, in Indiana, even covers a person who "entices, allures, instigates or aids any person under the age of twenty-one to commit masturbation. ..." 4 Ind. Stat. Ann. (Burns, r933) § 4221 .

${ }^{18}$ Citations to statutes are in the order adultery, fornication, lewdness, and sodomy. $\mathrm{Ab}$ sence of statutory provisions covering a given offense will be indicated by a dash in the approless indicated). Ariz. Code Ann. (I939) \& 43-40I; \$43-402; -; \$ $\$ 43-4 c 6,407$. Ark. Stat.

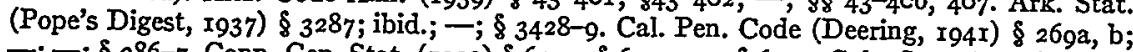
-; -; § 286-7. Conn. Gen. Stat. (I930) $\$ 6223 ; \S 6231 ;-; \S 6222$. Colo. Stat. Ann. (Michie, I935) C. 48, \& 203; ibid.; - ₹ 64. Del. Rev. Code (I935) \& 5258; - ; ; \& 5256. D. C. Code (1940) tit. 22, \& 30r; \& roor; -; (Supp. I949) tit. 22 (sodomy). Fla. Stat. (I94r) § 798. or; \$ 798.03; 798.02; \& 800.01-02. Ga. Code (I933) \& 26-5801; ibid.; \& 26-6101; \& 26-5901-4. Idaho Laws Ann. (Anderson, I932) § I7-1806; § I7-I808 (imposition expressly within discretion of the court); \& I7-1809; \& I7-1812-3. Ill. Rev. Stat. (I947) c. 38, §46-7; ibid. (and see below); -; \& I4I. 4 Ind. Stat. Ann. (Burns, I933) § I0-4207; ibid.; -; \& 10-420r. 2 Iowa Code (I946)

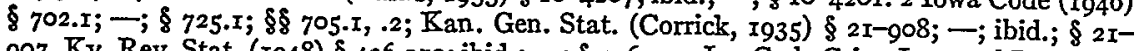
907. Ky. Rev. Stat. (I948) $\$ 436.070 ;$ ibid.; - $\$ 436.050$. La. Code Crim. Law and Procedure (Dart, I943) -; -; 一; § 740.89. 2 Me. Rev. Stat. (I944) c. I2I, $\S I ; \S 8 ; \S 5 ;$ \&. I Md. Ann. Code (Flack, I939) art. 27, $\$ 5 ;-;-; \S 577.9$. Mass. Ann. Laws (I933) c. 272, § 14; $\S 18 ;$ \& 16 ; ₹ 34. 24 Mich. Stat. Ann. (Henderson, I938) \& 28.218-2I; - (see below); \$28.567; $\$$ 28.355. 2 Minn. Stat. (1945) \& 6I7.I5; § 617.I6;-; §6I7.14. 2 Miss. Code Ann. (I942) § I998; ibid.; -; \$ 2413. Mo. Rev. Stat. (I939) § 4653; ibid.; ibid.; $\$ 4650.5$ Mont. Rev. Codes Ann. (Anderson \& McFarland, I935) \& I I006; ibid.; -; § Iro30. Neb. Rev. Stat. (I943) \& 28-902; \& 28-928-9; -; § 28-919. 5 Nev. Comp. Laws (Hilyer, 1929) § ror42; ibid.; ibid.; § I0I4I. 2 N.H. Rev. Laws (I942) c. 449, $\$ 1 ; \$ 4 ; \S 3 ; \S 9$. I N.J. Rev. Stat. (I937) tit. 2, c. I06, \& I; c. I33, \& I; c. I40, \& I; c. 168, \& I. 3 N.M. Stat. Ann. (I94r) \& 4I-702; ibid.; ibid.; § 4I-704. N.Y. Penal Law (McKinney, I944) c. 8, \& I00-2; -; ; c. 66, \& 69o. I N.C. Gen.Stat. (Michie, I943) § I4-184; ibid.; -; § I4-I77. N.D. Rev. Code (r943) § I2-2209-II; \& 2208; § 22I2; \$2207. Ohio Code Ann. (Throckmorton, 1948) § I3024; ibid.; - \$ \$; I3043. Okla. Stat. (I94I) tit. 2I, \& 871-2; -; -; \& 886. 3 Ore. Comp. Laws Ann. (I940) § 23-90I-2; \$ 23-903; -;

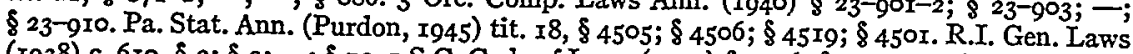
(I938) C. 6ro, § 2; \& 2;-; \& I2. I S.C. Code of Laws (I942) § I436; \& I437; -; § I439. x S.D. Code (r939) \& 13.3001-2; -; -; § I3.x716. Tenn. Code Ann. (Michie, 1938) -; - ; ; 8 Irr84. Tex. Ann. Pen. Code (Vernon, 1948) art. 499-50I; art. 503-4; -; art. 524. Utah Rev. Stat. Ann. (I933) \& I03-5I-3 (one section); \& IO3-5I-5; - ; IO3-5I-22. Vt. Pub. Laws (I933) $\$ 8600-2 ;$; $\$ 8611 ;-$ (see below). Va. Code Ann. (Michie, I942) \& 4543; ibid.; \& 4545; $\$ 455$. Wash. Rev. Stat. Ann. (Remington, Supp. 1940) $\& 2457 ;-; \S 2458 ; \S 2456$. W. Va. Code Ann. (Michie, r943) § 6058; ibid.; § 6059; \& 6068. 2 Wis. Stat. (Brossard, I947) § 35r.01; \$ 351.05; \& 35x.04; \& 35r.40. I Wyo. Comp. Stat. (I945) \& 9-503; ibid.; -; \$ 9-520. U.S. (applicable to territories and possessions), I8 U.S.C.A. \& 5 I6; \& 5 I8; -; - (I948).

The tabulation includes disorderly conduct statutes of Michigan and Illinois because they could be applied, unlike the states' other sex laws, to persons engaging in a single act of intercourse. Ill Rev. Stat. (1947) c. 38, \& I59; 24 Mich. Stat. Ann. (Reis, Supp. 1937) \& 28.364. In the absence of statutory provision sodomy is punished as at common law. All southern and many northern states have statutes prescribing severe penalties for miscegenation, but the constitutionality of such statutes is in doubt since a recent California decision, Perez v. Lippold, 32 Cal. 2d 7II, I98 P. 2d I7 (I948); Constitutionality of Anti-Miscegenation Statutes, 58 Yale I. J. 472, table at 480-8I (I949). These statutes have here been excluded because they are applied mainly to negro males, who are beyond the scope of this study. 
this in turn makes possible inclusion of those statutes in a study of private sex conduct. Also omitted from consideration are varied procedural requirements restricting instigation of suit, admission of evidence, and the time during which an action may be brought, as well as occasional narrow interpretations by appellate judges. ${ }^{19}$ Since data on average imposed penalties are not available,

TABLE 1

SCOPE OF SEX STATUTES

\begin{tabular}{|c|c|c|c|c|c|}
\hline \multirow{2}{*}{ OPFENSE } & \multirow{2}{*}{ Qualimication } & \multirow{2}{*}{$\begin{array}{l}\text { No. OF } \\
\text { STATES } \\
\text { WHERE } \\
\text { APPLY- } \\
\text { CABLE: }\end{array}$} & \multirow{2}{*}{$\begin{array}{l}\text { PER CENT } \\
\text { OR TOTAL } \\
\text { WEITE } \\
\text { MALE } \\
\text { POPULA- } \\
\text { CATION }\end{array}$} & \multicolumn{2}{|c|}{ Maxosfoni Punismasents (Where Defined) } \\
\hline & & & & Median & Range \\
\hline Adultery.... & $\begin{array}{l}\text { Single act } \\
\text { Habitual } \\
\text { Open, notorious, } \\
\text { and habitual } \\
\text { No crime }\end{array}$ & $\begin{array}{r}29 \\
12 \\
6 \\
2\end{array}$ & $\begin{array}{r}57.2 \\
30.0 \\
9.5 \\
3.3\end{array}$ & $\begin{array}{l}2 \text { yrs. pen. and } / \text { or } \$ r, \infty \\
6 \text { mos. and } / \text { or } \$ 500 \\
6 \text { mos. } \\
\ldots \ldots \ldots \ldots \ldots \ldots \ldots \ldots \ldots \ldots \ldots \ldots\end{array}$ & 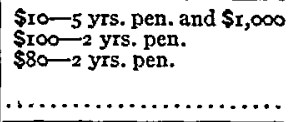 \\
\hline Fornication.. & $\begin{array}{l}\text { Single act (or pun- } \\
\text { ishable as disor- } \\
\text { derly conduct) } \dagger \\
\text { Habitual } \\
\text { Open, notorious, } \\
\text { and habitual } \\
\text { No crime }\end{array}$ & $\begin{array}{r}20 \\
11 \\
6 \\
12\end{array}$ & $\begin{array}{l}43.8 \\
22.1 \\
15.3 \\
28.8\end{array}$ & $\begin{array}{l}3 \text { mos. and/or } \$ r o o \\
6 \text { mos. } \\
1 \text { yr. and/or } \$ r, \infty \infty 0 \\
\ldots \ldots \ldots \ldots \ldots \ldots \ldots \ldots\end{array}$ & $\begin{array}{l}\$ 10-6 \text { mos. and/or } \$ 300 \\
\$ 100-\text { I yr. and } / \text { or } \$ 500 \\
\$ 80-3 \text { yrs. pen. } \\
\ldots \ldots \ldots \ldots \ldots \ldots \ldots \ldots \ldots\end{array}$ \\
\hline Lewdness.... & $\begin{array}{l}\text { Open and notorious } \\
\text { Lewd and lascivi- } \\
\text { ous behaviour } \\
\text { Lewd and lascivi- } \\
\text { ous behaviour, } \\
\text { open or not, de- } \\
\text { pending on mar- } \\
\text { ital status } \\
\text { No statutory crime }\end{array}$ & $\begin{array}{l}7 \\
2 \\
9\end{array}$ & $\begin{array}{r}15.5 \\
4.4 \\
18.5\end{array}$ & $\begin{array}{l}\text { I yr. and/or } \$ 500 \\
\ldots \ldots \ldots \ldots \ldots \ldots \ldots \ldots \\
\text { I yr. and/or } \$ 500\end{array}$ & $\begin{array}{l}6 \text { mos. and } / \text { or } \$ 200-5 \text { yrs. } \\
\text { pen. } \\
\text { I yr. and } / \text { or } \$ 500-\mathrm{yr} \text {. } \\
\text { chain gang } \\
\$ 500-5 \text { yrs. pen. }\end{array}$ \\
\hline Sodomy..... & $\begin{array}{l}\text { With mankind or } \\
\text { beast, etc. (usu- } \\
\text { al definitions) } \\
\text { Inciting to mas- } \\
\text { turbation in- } \\
\text { cluded }\end{array}$ & $\begin{array}{l}45 \\
2\end{array}$ & $\begin{array}{l}96.3 \\
3.0\end{array}$ & $\begin{array}{l}\text { Io yrs. pen. } \\
\ldots \ldots \ldots \ldots \ldots \ldots \ldots \ldots\end{array}$ & $\begin{array}{l}3 \text { yrs. pen. -life } \\
5 \text { yrs. pen. }-I_{4} \text { yrs. pen. }\end{array}$ \\
\hline
\end{tabular}

* Includes the District of Columbia.

"†"Disorderly conduct" in Illinois and Michigan; cf. note I8 supra.

ranges ${ }^{20}$ and medians ${ }^{21}$ of maximum penalties are included to indicate their distribution; but these are of little practical significace as regards the first three offense groups because, as to them, maximum sanctions are rarely invoked. Indeed, the diversity in punishment may be much less drastic in practice than the ranges would seem to indicate.

19 See Williams v. State, 64 Ind. 553 ( 1878 ), a case under a lewdness statute which prohibited indecent exposure in a public place. The defendants were having intercourse on a highway, to the amusement of sundry bystanders. Held that, in the absence of convincing proof that it was being habitually travelled upon at the time and place of the act, the highway was not a "public place" within the meaning of the statute.

${ }^{20}$ Range: The difference between the least and greatest value in a series; also the extent of the series.

21 Median: A point so chosen in a series that half of the individuals in the series are on one side of it, and half on the other. Webster's Collegiate Dictionary 62I (Merriam's 5th ed. I946). 
With the aid of the Kinsey Report's figures it is possible to determine the percentage of white males whose acts would subject them to prosecution under the above sex statutes. Kinsey claims that:

$\ldots 85$ per cent of the total male population has premarital intercourse $\ldots, 59$ per cent has some experience in mouth-genital contacts..., nearly 70 per cent has relations with prostitutes..., something between 30 and 45 per cent has extra-marital intercourse $\ldots, 37$ per cent has some homosexual experience..., I7 per cent of the farm boys have animal intercourse.... All of these... are illicit activities, each of which is punishable as a crime under the law. The persons involved in these activities, taken as a whole, constitute more than 95 per cent of the total male population ... for which the judge, or ... church, or civic group demands apprehension, arrest, and conviction, when they call for a clean-up of sex offenders in a community. It is, in fine, a proposal that 5 per cent of the population should support the other 95 per cent in penal institutions. ${ }^{22}$

As formulated, the last statement is untenable. It rests upon the false assumptions that $r$ ) all states outlaw all of the indicated behavior (an error already corrected in Table I, supra.), and 2) that, if the act were committed at any time during the offender's life, he would thereafter permanently remain criminally liable. As most statutes bar prosecution on a sex charge upon the lapse of a relatively short time after the offense, ${ }^{23}$ the number of persons who have ever been criminally liable is irrelevant from the point of view of law enforcement at any given time. That portion of the population which is actively engaging in an illicit sex act during a given short period (active incidence) is substantially lower than the portion who have ever done, or will ever do, such an act during their lives, or by the time they reach a given age (accumulative incidence). Thus the sex acts which an adult of thirty may have committed during his life might greatly outnumber the acts which he is currently committing as well as those for which he is still subject to prosecution where the statute of limitations has not run. But because Kinsey is more interested in the behavior pattern of a homogeneous age group ${ }^{24}$ than in that of a heterogeneous age group at a given time, many of his statistics are only presented as accumulative incidences. For the purpose of this study it has been necessary, in order to determine temporary sex criminality, to choose a reasonable proportion of accumulative incidence as active incidence. ${ }^{25}$

22 Kinsey, op. cit. supra note $I$, at 392.

${ }^{23}$ For example, Mich., Minn., N.D., Ore., and Wash. require that prosecutions for adultery be initiated within one year after the offense. California has a one year statute of limitations applicable to all misdemeanors, while such states as Illinois and Nerw York allow two years. The foregoing does not purport to be an exhaustive listing, and of course does not apply to offenses classified as felonies (such as sodomy and some forms of lewdness) for which the statute may allow a much longer period. poses.

24 E.g., all males 20-24 years of age, a grouping which is more significant for clinical pur-

${ }^{25}$ Kinsey is admittedly inconsistent in his use of accumulative incidence techniques: cf. Kinsey, op. cit. supra note $I$, at $I 14-I 9$. But compare table 94, ibid., at 370 . In using this table 
Implicit in the definition of certain offenses is the requirement of a minimum rate of repeated commission of an act. To determine the number punishable for such an offense it becomes necessary to ascertain those who at a given time are engaging in the conduct sufficiently often. For example, the provisions of a statute outlawing association in a "state of adultery" may include persons whose extramarital intercourse occurs only a few scattered times per year. ${ }^{20}$ Unlike statistical means, averages which are greatly thrown off by extreme high or low frequencies, medians or other graphs indicating the distribution of frequencies can be used for a rough estimate of that segment of the population whose rate of performing the act exceeds the required minimum. ${ }^{27}$ As the frequency rates of the general population were needed to establish the offense coverage of the statutes, and since the Report neglected medians or other distribution graphs for the United States population but furnished medians for the frequencies of the sample population, the approximations for group frequencies used below were derived from those given for the sample. Appropriate adjustments discussed in the notes, ${ }^{28}$ were made in projecting Kinsey's sample figures to the population as a whole.

Although the restriction of this inquiry to voluntary private sex acts results in the exclusion of certain sex offenses included by Kinsey to achieve his totals, little error even for comparative purposes is introduced in the figures below. Any person who is engaging in one illegal sex act during the period will be deemed "subject to prosecution"; hence only persons who engage exclusively in one of the omitted sex activities would not be represented in the totals. Prostitution can thus be omitted because of the very small number of men who rely on it alone for their intercourse outlet, and also because the relevant statutes are directed primarily against the prostitute and her business associates, and only incidentally, if at all, against the male "customer." ${ }^{2 \theta}$ Because active inci-

in the absence of more precise data, one-half the accumulative incidence was here arbitrarily selected as the active incidence; a percentage which, particularly as to oral eroticism, errs on the side of bigness.

${ }^{26}$ Where "living together" or "cohabitation" in such a state is required in addition, even daily repeated intercourse may be insufficient to establish the offense in the absence of a showing that the parties lived under the same roof. This additional qualification has been omitted in the calculations for Table 2 , infra, because of the caprice of judicial interpretation, but as a result the percentages there are overstated.

${ }^{27}$ Medians are inferior to other distribution graphs because they give no clue as to the change of the frequency rate on either side of the midpoint.

${ }^{28}$ The difficulties in deriving the number of persons engaging in a given act at a required minimum rate are illustrated in the use of Table 54 , Kinsey, op. cit. supra note 1 , at 248 . The median frequencies for extra-marital intercourse among the total sample population (column 4) are there listed as 0.00 acts per week, but the average median for the active sample population (column 8) is high enough to qualify one-half of the actives as offenders. Since no median is furnished for the U.S. corrected figures, (columns ro-I5) but active incidences are given, onehalf of the U.S. corrected active incidence (column $x_{3}$ ) was the percentage chosen as "subject to prosecution."

${ }^{29}$ Of the 35.3 per cent of the population not subject to prosecution for other single acts of non-marital intercourse, only .2 per cent are so punishable for visiting a house of prostitution. 
dence for animal intercourse is very low even among farm boys and insignifcant as applied to the total population, the figures have been excluded. ${ }^{30}$ Statutory rape, a relatively frequent subject of prosecution for which no incidence figures have been given, probably constitutes only an extremely small source of exclusive illegal sex outlet except for young people of approximately the same age. The boy's youth may then place him within the jurisdiction of a juvenile court and thus exempt him from the statutory sanctions. ${ }^{31}$

The widespread existence of juvenile courts is also responsible for fixing the lower age limit of this survey to sixteen. Although this excludes offenders younger than sixteen who must undergo some form of punishment, it will include older offenders who may often escape any real punishment because of the concurrent misdemeanor jurisdiction of a juvenile court over persons to I8 or even 2 I years of age. Limitations in Kinsey's present data for older groups necessitated fixing of the upper age limit at sixty. ${ }^{32}$

While the percentages shown in Table 2 are less sensational than the 95

TABLE 2

Percentage of POPULATION SUbJECT TO PROSECUTION For VOLUNTARY SEX ACTS

\begin{tabular}{|c|c|c|c|c|c|c|c|}
\hline & \multicolumn{2}{|c|}{ Sngete Whte MaLes } & \multicolumn{2}{|c|}{$\begin{array}{c}\text { MaRried } \\
\text { Wirte MLaLES }\end{array}$} & \multicolumn{3}{|c|}{ Total White Males } \\
\hline & $\begin{array}{l}\text { Single } \\
\text { Acts }\end{array}$ & $\begin{array}{c}\text { Habitual } \\
\text { Acts }\end{array}$ & $\begin{array}{l}\text { Single } \\
\text { Acts }\end{array}$ & $\begin{array}{l}\text { Habitual } \\
\text { Acts }\end{array}$ & $\begin{array}{l}\text { Single } \\
\text { Acts }\end{array}$ & $\begin{array}{c}\text { Eabitual } \\
\text { Acts }\end{array}$ & $\begin{array}{l}\text { Total } \\
\text { Acts }\end{array}$ \\
\hline $\begin{array}{l}\text { Percentage of total white } \\
\text { male population...... }\end{array}$ & $\mathrm{I} 4 \cdot 5$ & 1.9 & I2.I & I. 8 & 26.6 & $3 \cdot 7$ & 30.3 \\
\hline $\begin{array}{l}\text { Percentage of white male } \\
\text { population ages } I 6-60 .\end{array}$ & \multicolumn{2}{|c|}{25.9} & \multicolumn{2}{|c|}{22.0} & $42 . I$ & 5.8 & $47 \cdot 9$ \\
\hline
\end{tabular}

American Social Hygiene Association, Digest of Laws Dealing with Prostitution and Other Sex Offenses (1942). But in many states "customers" may fall within vagrancy statutes not included in the above compilation, and the federal Mann Act as well as similar state enactments have not been applied exclusively to white slave traffic but have snared mere unwary fornicators. Compare note $6_{7}$ infra.

${ }^{30}$ For the total population, only a fraction of one percent of the total number of orgasms is derived from animal intercourse. Kinsey, op. cit. supra note $r$, at 670 ; ibid., figures $128-30$, at $490-9 r$.

${ }^{31}$ See Lyman, Analysis and Tabular Summary of State Laws Relating to Jurisdiction in Children's Cases [etc.] in the United States (I930).

82 The Kinsey percentage cited in the text presumably includes all age groups. Restriction of this study to ages r6-60, however, still permits a valid comparison of the two sets of data. As pointed out in the text, the fixing of the lower age limit virtually accounts for all punishable youthful offenders. The sample for age groups above forty-five is much smaller than the 300 which Kinsey considers most adequate; see Kinsey, op. cit. supra note I, at 85-88, also generally ibid., c. 7. Where better data were not available, ages $45^{-60}$ have been carried at the higher rates of age 45 . The resulting overstatement is probably large enough to account for the virile males over sixty which are represented in the Kinsey figures. 
per cent estimated by Kinsey, they do show that under our present sex statutes a substantial portion of the population, particularly of the income-earning group of which men between sixteen and sixty are by far the largest component, ${ }^{33}$ is engaging in illicit sex conduct at any given time.

\section{II}

The preventive effect of a sex statute, operative in a domain where other social forces exercise a strong deterrence, cannot be gauged directly. But it is immediately affected by the degree of enforcement which is a measurable quantitative correlation between offense and conviction. Because of statistical limitations only the less valuable comparison between the number of arrests and that of offenders can here be established. Even then a difficulty arises out of the present lack of diversity of Kinsey's overall sample which is mainly taken from a limited geographic area. ${ }^{34}$ Because the geographic variation in sex behavior is indicated as substantial, ${ }^{35}$ the analysis of enforcement here attempted is confirmed to two regions: the East North Central States (ENC), comprising Illinois, Indiana, Michigan, Ohio, and Wisconsin; and the Middle Atlantic States (MA), including New Jersey, New York, and Pennsylvania. Because the criminal statistics compiled by the Federal Bureau of Investigation ${ }^{36}$ and relied on here do not list rural data for "Class 2 " crimes which include "other sex offenses," a further restriction to urban white males only is required in this study.

The years r938-I947, which include the later war years when millions of men were beyond the reach of state criminal statutes, present a convenient period for investigation. The number of offenders is taken from F.B.I. tables showing the number of persons "charged" (held for prosecution). 37 The table which lists the age of offenders segregates age " 50 and over" in one group. Error is thus introduced by the possible inclusion of offenders over sixty, but according to population statistics their number is too small to affect the application of the enforcement data to the Kinsey data, which sets the upper age limit at sixty. Since age breakdowns by sex and race are not given, it has been assumed that they are the same for males and females as well as for the white and nonwhite population. Finally, the Uniform Crime Reports give relevant data only for a substantial portion of the total urban $^{38}$ population. The statistics for

${ }^{33} 69.4$ per cent. Calculations from Sixteenth Census, Part I, Vol. III, table 5, at I9 (rg40).

${ }^{34} \mathrm{Kinsey,} \mathrm{op.} \mathrm{cit.} \mathrm{supra} \mathrm{note} \mathrm{I}$, fig. I, at 5 . The distribution there shown is inaccurate because it includes female histories also.

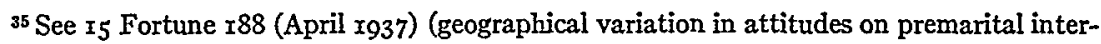
course).

${ }^{36}$ Uniform Crime Reports (compiled semi-annually).

${ }^{37}$ See, typically, Ig Unif. Crime Rep. 54, table I8 (r948). Together with the number of persons released without being charged, the number of persons held for prosecution indicates the total arrest activity by the police.

s8 "Urban" here does not connote "metropolitan"; more than half of the "cities" reported have less than 10,000 inhabitants. Ibid., at 5 . 
"persons charged" have therefore been corrected for urban coverage, race, sex, and age. ${ }^{39}$ Table 4 indicates the number of urban white males, ages $16-60$, who could be prosecuted for sex offenses in the two regions. ${ }^{40}$ For the two regions combined, which contain 60.3 per cent of the total urban white male population of the United States, out of $4, I 5^{I, 800}$ offenders subject to prose-

TABLET3

AVERAGE NUMBER OF SEX OFFENDERS I938-47

\begin{tabular}{|c|c|c|c|c|}
\hline \multirow{2}{*}{ YeAR } & \multicolumn{2}{|c|}{$\begin{array}{l}\text { Urban Population Covered by } \\
\text { Crminal Statistics } \\
\text { (n Thodsands) }\end{array}$} & \multicolumn{2}{|c|}{$\begin{array}{l}\text { Number of Ofmanders } \\
\text { ("Persons Charged") }\end{array}$} \\
\hline & $\mathbf{M A}^{*}$ & ENCt & MA & ENC \\
\hline 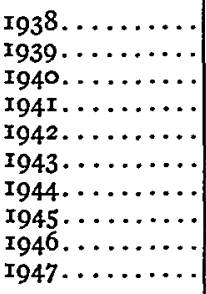 & $\begin{array}{l}7,651 \\
7,914 \\
8,098 \\
7,637 \\
7,631 \\
8,768 \\
9,412 \\
9,672 \\
9,472 \\
9,813\end{array}$ & $\begin{array}{r}13,186 \\
I_{3}, 824 \\
13,822 \\
I_{3}, 443 \\
7,527 \\
13,951 \\
14,441 \\
14,832 \\
14,749 \\
I_{5}, r_{26}\end{array}$ & $\begin{array}{l}I, 250 \\
I, I 68 \\
I, 203 \\
I, 4 I 8 \\
I, I 30 \\
I, 557 \\
I, 604 \\
I, 78 I \\
I, 996 \\
2,2 I 8\end{array}$ & $\begin{array}{l}2,615 \\
2,966 \\
3,020 \\
3,189 \\
2,000 \\
4,267 \\
4,135 \\
4,179 \\
5,314 \\
5, \text { I74 }\end{array}$ \\
\hline Average. ...... & 8,607 & $I_{3}, 490$ & $I, 533$ & 3,686 \\
\hline \multicolumn{3}{|c|}{ Average no. of offenders, as corrected....... } & 2,270 & $2,9 \times 2$ \\
\hline
\end{tabular}

Average corrected no. of offenders, $M A$ and ENC............ 5,182

* Middle Atlantic states.

† East North Central states.

cution (Table 4) only 5,I82, or .I2 per cent, actually have been charged (Table 3), leaving 99.88 per cent not charged. For the Middle Atlantic States region only, the Judicial Criminal Statistics provide fairly reliable data on the average percentage of convictions. Of 2,275 persons charged, 70.5 per cent have been convicted. However, out of $2,588,900$ persons subject to prosecution, only .06 per cent have been charged and convicted. ${ }^{41}$

39 For the East North Central States, the calculations were: 3,686 (average number of offenders "charged") times $\mathrm{I.29}$ (correction factor for total urban population) times .783 (combined correction factor for per cent of males and age) times .78x (correction factor for per cent of whites).

${ }^{40}$ The Line I figures are obtained for the regions in the same manner as Table 2 was compiled for the entire country.

11 Even these figures are swollen as regards the statistically most common act of nonmarital heterosexual intercourse. A positive correlation probably exists between the notoriety of the offense and the number of arrests made, so that most persons charged with "other sex offenses" may be homosexuals or other sodomists and exhibitionists. 
This law enforcement failure may be traced to the difficulties inherent in the enforcement process itself, and to a substantial difference between the mores of current society and those of the framers of the statutes. Limited police personnel, constitutional and procedural safeguards, politics, and difficulties inherent in detection hamper enforcement of almost any criminal statute. ${ }^{42}$ Although the apparent contrast between current mores and positive law may seem peculiar, ${ }^{43}$ it must be remembered that these statutes were enacted originally to apply to an ethnically homogeneous population whose mores were not too far

TABLE 4

PERSONS "SUBJECT TO PROSECUTION" FOR THE COMMISSTON OF "OTHER SEX OFFENSES"

\begin{tabular}{|c|c|c|c|}
\hline Line & & MA & ENC \\
\hline I.. & $\begin{array}{l}\text { Percentage of total white male population punish- } \\
\text { able for any sex offense (ages } I 6-60 \text { ) }\end{array}$ & 26.4 & I9.4 \\
\hline $2 \ldots \ldots$ & $\begin{array}{l}\text { Percentage of total white male population in these } \\
\text { states who are "urban" residents }\end{array}$ & 75.2 & 63.0 \\
\hline 3. & $\begin{array}{l}\text { Percentage of total white male population punish- } \\
\text { able for any sex offense (urban, ages I6-60; line } \\
\text { I times line 2) }\end{array}$ & xg.9 & $\times 2.2$ \\
\hline $\begin{array}{l}4 \cdots \\
5 \cdots\end{array}$ & $\begin{array}{l}\text { Total white male population (in thousands) } \\
\text { Urban white males ages I6-60 subject to prose- } \\
\text { cution (line } 3 \text { times line } 4 \text { ) }\end{array}$ & $\begin{array}{r}13,084 \\
2,588,900\end{array}$ & $\begin{array}{r}12,893 \\
\mathrm{r}, 5^{62,900}\end{array}$ \\
\hline
\end{tabular}

removed from those of their self-righteous Puritan leaders. ${ }^{44}$ The statutes are periodically re-enacted and penalities are altered to conform to current practice, but these are routine legislative matters over which the public at large exercises little control.

The mere fact that a person does not initiate the prosecution of a particular sex offender neither indicates that person's approval of the conduct nor his desire to eliminate the law. ${ }^{45}$ But since this condonation may well be the crux of the enforcement problem, it seems worthwhile to inquire into possible motives for the initiation of prosecution, ${ }^{46}$ apart from a mere general moral disap-

42 These ordinary enforcement difficulties hamper the clearance by the police of even serious crimes, and account for the fact that in 1947 approximately 20 per cent of major crimes against the person and 75 per cent of major crimes against property were admittedly not cleared by arrests. Kinsey, op. cit. supra note $3 \mathrm{I}$, at 48 .

43 Theoretically, the majority in a democracy would be able to repeal laws which do not mirror its mores. In practice, it is well known that organized minority groups bring greater weight to bear on a legislature than does an apathetic and heterogeneous majority. Fuller, Morals and the Criminal Law, $32 \mathrm{~J}$. Crim. Law 624 (I942).

44 May, Social Control of Sex Expression 259 (I936).

${ }_{45}$ No logic compels to an inference that $A$ approves of an act $X$ outlawed under a statute $\mathrm{S}$ when done by $\mathrm{B}$, merely because $\mathrm{A}$ does not want to have $\mathrm{B}$ prosecuted. A may dislike $\mathrm{X}$ but dislike $S$ more, or merely dislike $S$ when applied to $B$.

${ }^{46}$ Dean Pound considers the necessity of providing motives for the initiation of prosecution one of the three major limitations of law as an agency of social control. The others are "the 
proval. Motivation may depend on the extent to which a given act affects the marital relation. Thus a spouse may seek criminal law redress for the unfaithfulness of the other. It is significant to note, however, that although thousands of divorces are granted annually, and although adultery is one of the major grounds for divorce because it is one of the few such grounds recognized by nearly all states, the number of prosecuted adulterers is negligible, even though the facts constituting the crime are here directly before a court. ${ }^{47}$ Civil actions for criminal conversation, now eliminated in many states, ${ }^{48}$ rarely if ever result in the criminal prosecution of the defendant under the applicable adultery statutes. Wigmore does not list a single case of intra-marital sodomy in his exhaustive enumeration of the exceptions to a defendant's privilege against the admission of testimony of a spouse, although this is clearly a crime otherwise falling within the exceptions. ${ }^{49}$ The scandal involved in the initiation of prosecution and the virtual impossibility of convincing the jury on the testimony of a participant to the act deters the most hardy.

The only motive of any practical significance in seeking prosecution of private nonmarital (as distinguished from extramarital) ${ }^{50}$ sex acts would seem to be spite which may arise from a transaction unrelated to the act itself. But the prosecuting witness may subject himself to the penalties he seeks to have applied to the defendant, and if the witness is a female, as is the rule, her reputation would be marred by notice of her participation. While an offense like nonmarital sodomy might itself impel initiation of prosecution because of a genuinely outraged sense of decency, outsiders do not get a chance to observe another's sex conduct except accidentally or unless purposely violating the privacy sought by the participants.

In the absence of a statistical determination of the maximum extent to which the normal administrative difficulties influence enforcement, it cannot be demonstrated that the divergence between law and mores is in itself sufficient to account for the breakdown. ${ }^{51}$ But it seems reasonable to conclude that this gap is a prime causal factor.

necessity which the law is under . . of dealing only with the outside . . of men and things," and "the limitations inherent in the legal sanctions. ..." Pound, The Task of Law 72 (I944).

17 "In New York state something like 5,000 divorces are granted annually. If the law were duly enforced we should expect in that state something like Io,ooo convictions each year for adultery. As a matter of fact there are practically none. ..." Butler, Sex and the Law, 9o Survey Graphic 242 (1936); see also 2 Simpson and Stone, I aw and Society $\times 582$ n. 2 (1949).

${ }^{18}$ See generally Feinsinger, Legislative Attack on "Heart Balm," 33 Mich. L. Rev. 979 (1935).

19 The exceptions, based upon personal wrongs done to the wife, are listed in 8 Wigmore, Evidence $\$ 2239$ ( 3 d ed. I940).

so In Kinsey's terminology, "nonmarital" refers to the sex activities of the single male, "extra-marital" to the "extra-curricular" acts of the husband.

s1 The demonstration could be made by establishing a statistical "threshhold" as the minimum possible enforcement ratio due to the action of all ordinary deterrent factors. Anything lower than this percentage would necessarily indicate the causal sufficiency of the rift factor. 
Although the vast majority of sex offenders are conclusively disposed of by police and magisterial courts, ${ }^{52}$ these primary enforcement echelons are bound by the law as interpreted upon appellate judicial review. Appellate judges, unlike most policemen and magisterial officials whose appointments rarely depend on academic qualifications, ${ }^{53}$ generally come from "upper" classes and have had the opportunity to acquire considerable formal education. Of forty-two appellate judges in twenty jurisdictions sitting in sex offense cases during the period investigated, thirty-nine belonged to Kinsey's "I 3 -plus" and at least thirty had graduate college degrees. ${ }^{55}$ If Kinsey's theory on the negative correlation between status and sex activity is correct, ${ }^{56}$ and if a low rate of activity implies lack of toleration for the promiscuous rates and divergent practices of others, the mores of the judiciary should be reflected in decisions giving a broad scope to the sex laws under review which would then offset the enforcement apathy of the first-instance agencies.

The accuracy of the foregoing proposition cannot be proved because the number of sex cases appealed is too small, and the diversity of conduct passed upon too limited to permit comparison with offenses finally disposed of in the first instance. During the period $1938-47$ only II 6 appeals dealing with offenses herein considered were reported nationally. ${ }^{57}$ Of these, 72 , or 62 per cent, dealt with sodomy, presumably because the penalities for that crime are far more severe than those prescribed for the other offenses and thus render the large expense of an appeal worth while.

Appellate reversals, even where based on substantive grounds, do not necessarily indicate either the discharge of the defendant or the judge's social attitude. ${ }^{58}$ Considerable leeway for the exercise of judicial discretion is presented by questions on the sufficiency of the evidence which account for 63 per cent of all reversals on substance during the period. ${ }^{59}$

${ }^{52}$ Included are municipal and other criminal courts of general primary jurisdiction.

${ }^{53}$ The diverse and non-legal background of magistrates is illustrated in Ervin, The Magistrates' Courts of Philadelphia IO4 (I93I).

54 "I3 +" denotes persons having had one or more years of college training or an equivalent education. Kinsey, op. cit. supra note I, at 77 ; ibid., c. ro.

${ }^{85} 73$ judges handed down appellate sex opinions during the period, but the biographical records of only 42 were available, mainly from Who's Who in Law (I937).

${ }^{56} \mathrm{Kinsey}$ claims the existence of a negative correlation between attained education and amount of nonmarital intercourse, and of a positive correlation between social level and variety of sex experience. Kinsey, op. cit. supra note r, c. Io.

${ }^{57}$ Space limitation prevents citation of the cases, which were taken from the General Digest of the West System for this period, under the headings Adultery, Fornication, Lewdness, and Sodomy.

${ }^{58} \mathrm{~A}$ survey of the fact situations of the appealed cases to determine what fact groupings judges consider most relevant in reaching their decisions, thereby obtaining a clue to their prejudices, proved inconclusive, partly because there is a prudish hesitancy to fully describe the facts pertaining to sex offenses in an opinion.

59 The isolation in which parties usually engage in voluntary sex relations, and the fact that many states prohibit convictions resting solely on the uncorroborated testimony of an "ac- 
Only cases where at least one of the defendants is a male are listed in the tabulation of appellate dispositions in Table 5. The trend indicated by the very high percentage of reversals on nonsodomy appeals tends to contradict

TABLE 5

APPELLATE SEX Decisions I938-47

\begin{tabular}{|c|c|c|c|c|c|c|c|c|}
\hline & Total & Aff'd & $\begin{array}{l}\text { Per } \\
\text { Cent }\end{array}$ & $\begin{array}{l}\text { Rev'd } \\
\text { Subst. }\end{array}$ & $\begin{array}{l}\text { Per } \\
\text { Cent }\end{array}$ & $\begin{array}{l}\text { Rev'd } \\
\text { Proced. }\end{array}$ & $\begin{array}{l}\text { Per } \\
\text { Cent }\end{array}$ & $\begin{array}{l}\text { Per Cent } \\
\text { Total } \\
\text { Rev'd }\end{array}$ \\
\hline $\begin{array}{l}\text { Fornication... } \\
\text { Adultery..... } \\
\text { Lewdness..... }\end{array}$ & $\begin{array}{l}\text { I5 } \\
\text { I2 } \\
\text { I7 }\end{array}$ & $\begin{array}{l}7 \\
4 \\
7\end{array}$ & $\mid \begin{array}{c}\ldots \ldots \\
\cdots \\
\cdots\end{array}$ & $\begin{array}{r}5 \\
7 \\
\text { I0 }\end{array}$ & $\begin{array}{l}33 \cdot 3 \\
58 \cdot 3 \\
58 \cdot 9\end{array}$ & $\begin{array}{c}3 \\
I \\
\ldots \ldots \ldots\end{array}$ & $\begin{array}{r}20.0 \\
8.3 \\
\ldots \ldots\end{array}$ & $\begin{array}{l}53 \cdot 3 \\
66.6 \\
58.9\end{array}$ \\
\hline $\begin{array}{r}\text { Subtotal.... } \\
\text { Sodomy..... }\end{array}$ & $\begin{array}{l}44 \\
72\end{array}$ & $\begin{array}{l}18 \\
57\end{array}$ & $\begin{array}{l}4 I .0 \\
79.2\end{array}$ & $\begin{array}{l}22 \\
12\end{array}$ & $\begin{array}{l}50.0 \\
16.7\end{array}$ & $\begin{array}{l}4 \\
3\end{array}$ & $\begin{array}{l}9.0 \\
4.1\end{array}$ & $\begin{array}{l}59.0 \\
20.8\end{array}$ \\
\hline Total... & 126 & 75 & 64.7 & 34 & $29 \cdot 3$ & 7 & 6.0 & $35 \cdot 3$ \\
\hline
\end{tabular}

Kinsey's assertions on the sexual intolerance of the judiciary and on an alleged correlation between class status and the condonation of private voluntary sex acts. $^{60}$

\section{III}

The foregoing sections indicate that laws restricting private voluntary sex expression are rarely enforced. While widespread practice ordinarily is linked with an attitude of approval, some or all of these acts, as Kinsey also observed, ${ }^{61}$ are still widely disapproved. This disapproval varies with the known

complice" prosecuting witness, force the trial courts to rely freely on circumstantial evidence of questionable probative value.

${ }^{60}$ "On sex cases, the decisions of the judge on the bench are often affected by the mores of the group from which he originated. Judges often come from better educated groups, and their severe condemnation of sex offenders is largely a defense of the code of their own social level. Lower level individuals simply do not understand the bitter denunciations which many a judge heaps upon the lower level boy or girl who has been involved in sexual relations." Or "[j]udges who are ignorant of the way in which the other three-quarters of the population lives [sic], naively believe that the police officials are apprehending all of those who are involved in any material infraction of the sex laws." Kinsey, op. cit. supra note $x$, at 390-99 (italics added). Compare Fake, J.: "Assuming arguendo that the petitioner here is found to have fornicated within the meaning of the law ... can this conclusion, in the realm of the law, be arrived at without carrying the blight of immorality with it? I think it can. The true character of a man is largely, if not entirely, hidden in the secret recesses of his mind. Only by his conduct and by his words arewe able to obtain any evidence of it. Moreover, as we have seen the generally accepted rules of morality ... fluctuate in each era and the best we can do with the subject is to apply the generally accepted rules of our own day." Pet. of Smith, 7 I F. Supp. 968,972 (D.C. N.J., I947) (petition for naturalization). In a very recent New York case, the Appellate Division upheld an award of custody of her minor daughters to a woman divorced because of her belief in and practice of extra-marital sexual experimentation, but the Court of Appeals reversed, two judges dissenting. Bunim v. Bunim, 273 App. Div. 86r, $7^{\circ}$ N.Y.S. 2d 45 (I948), rev'd 83 N.E. $2 d 848$ (I949).

61 Kinsey, op cit. supra note I, at 384 (homosexuality), 584 (extra-marital intercourse). 
or surmised frequency of a given act in the critic's own social and economic subgroup $;^{62}$ reasons for disapproval are, however, substantially the same for all the offenses here considered. The pressure of organized moral and religious groups, ${ }^{63}$ social pressure for early marriage and legitimate children, ${ }^{64}$ and the efforts of public agencies seeking to prevent the spread of venereal disease, ${ }^{65}$ partly account for this disapproval. Assuming, arguendo, that for these or other reasons a majority of the population still publicly castigates nonmarital private voluntary sex relations, it may still be asked whether the criminal law is a suitable medium for the effective expression of this disapproval.

Some who answer affirmatively may feel that legal sanctions are essential to provide the desired deterrent and reformative effect. Since deterrent effect is directly proportional to the degree the law is known to be enforced, advocates of this point of view should logically press for more vigorous enforcement.

The difficulties inherent in this approach are strikingly illustrated by a wartime government campaign. After the passage of the Selective Service Act in I940 the government became increasingly concerned over venereal disease as a factor in reducing available manpower. This concern led to the May Act ${ }^{66}$ which provided that civilian activities abetting "lewdness, assignation, or prostitution" in the vicinity of army and navy camps would be punishable as a federal offense. While this act was ostensibly directed at professional prostitution, settled judicial misinterpretation of the Mann Act ${ }^{67}$ opened the door to possible federal intervention in the enforcement of all state sex laws within the prescribed

62 Ibid., at $384-86$.

${ }^{63}$ The church, however, has not always practiced what it preaches. Thus "[ $[$ ]he London citizens used to arrest fornicating chaplains and put them in the tun as night-walkers; in 1297 the bishop objected and the practice was forbidden. Munim. Guildh. ii. 213." 2 Pollock and Maitland, History of English Law 543 n. 5 (2d ed. I89g). See May, Social Control of Sex Expression, c. 6 (I936). An intelligent modern clerical viewpoint is presented by Gardiner, Moral and Ethical Considerations in Relation to the Report II, in Problems of Sexual Behavior 73 (I948).

${ }^{64} \mathrm{~A}$ reduction in the sexual pressure toward early marriage, by lifting criminal sanctions from nonmarital intercourse, might result in keeping young women in the labor market for a few additional years, a situation which, if it resulted in an excess supply of labor, might tend to depress wages. Query whether an increase in the birth rate is desirable or significant in the atomic age; a recent House of Lords decision does not consider the existence of a possibility of procreation as essential to "consummate" a marriage. Baxter v. Baxter, [1948] A.C. 274. Concerning the legal scope of this case, see Gower, Baxter v. Baxter in Perspective, II Modern I. Rev. I 76 (1948). The financial problem raised by the state's duty to maintain, at public expense, illegitimate children who have no other means of support may be more serious.

${ }^{65}$ The Iater stages of syphilis may lead to insanity and force impecunious victims into already overcrowded state mental institutions. "Sanitary" practices of abortion mills have been the subject of widespread adverse comment.

${ }^{66} 55$ Stat. 583 (I94I), I8 U.S.C. § 1384 (r948).

${ }^{67}$ I8 U.S.C. $\$ \$ 242 I-23$ (I948); Cleveland v. United States, 329 U.S. I4 (I946); Caminetti v. United States, 242 U.S. 470 (I9I7); King v. United States, 55 F. 2 d ro58 (C.C.A. roth, I932). Taylor, Manhandling the Mann Act, 5 Nat. Bar. J. 39 (I947); Rogers, The Mann Act and Non-Commercial Vice, 36 Law Notes Io7 (1933). 
areas. ${ }^{88}$ It was soon recognized that professional prostitutes accounted for only a small minority of the infections, the majority of which were passed along by civilian "victory girls." campaigns, the surprisingly large number of convictions ${ }^{70}$ leaves little doubt that its terms were "liberally" construed by the enforcing federal agents. At the same time heavy pressure was brought to bear on local agencies to enforce long dormant state sex laws. The Social Protection Division of the Office of Community War Services, a subsidiary of the Federal Security Agency, issued detailed "advisory" material for the use of local police, ${ }^{71}$ and also attempted to co-ordinate the activities of federal and state agencies, ${ }^{72}$ including the United States Public Health Service, which is normally concerned with venereal disease control. The resulting restrictions on business and freedom of movement after dark would hardly be tolerated in any community during peacetime, but venereal infections continued with but slight occasional abatement. Not until the services, which originally placed much reliance in a persuasive but ineffective espousal of continence, adopted a policy of virtually mandatory prophylaxis for those who had an opportunity for off-camp contacts, did the rate of venereal infection show a permanent decline, a fact which would indicate that the reduction in total nonmarital intercourse was probably negligible.

The social cost of effective enforcement might be far greater than the evils sought to be suppressed. Twenty years ago the entire administration of law was on the verge of disintegration over the attempted enforcement of prohibition legislation. ${ }^{73}$ The search and seizure cases decided during that era ${ }^{74}$ indicate

${ }^{68} \mathrm{Mr}$. J. Edgar Hoover, in a letter to the University of Chicago Law Review dated Feb. 2, I949, insists that FBI agents assist in the apprehension of sex law violators only where some federal law has been violated, but that investigative assistance only is available to local law enforcement officials in the processing in the FBI laboratory of evidence relating to sex offenses.

69 "Army and Navy reports show a great majority of infections traceable to 'free' girls, or 'pickups." "Calling All Communities, American Social Hygiene Association, Publication No. A-575 (I945).

70 In the two areas, Fort Bragg, N.C., and Camp Forrest, Tenn., FBI special agents secured the conviction of 784 "prostitutes and procurers" up to January 3 I, I944. Pennington, The Challenge to Law Enforcement, 30 J. Soc. Hyg. 530, 535 (I944). This figure might not seem excessive because more than 30,000 persons were charged with prostitution and commercialized vice during 1943. I5 Unif. Crim Rep., table 14 at 35 (1944). However, Table 3 in the text indicates that during $1943-44$, when about ten million active men were beyond the reach of state sex laws, there was no appreciable decline in the prosecution of sex offenders, from which it may be inferred that at least the threat of federal intervention kept state police active.

7 See, for example, Techniques of Law Enforcement in the Use of Policewomen with Special Reference to Social Protection (x945); Techniques of Law Enforcement against Prostitution (I943).

72 "The Social Protection Division aids communities in controlling venereal disease through law enforcement for repression of prostitution and promiscuity." Services of the Federal Security Agency I7 (1944) (italics added).

75 See Enforcement of the Prohibition Laws [Wickersham Report], Sen. Doc. 307, 7Ist Cong. 3 d Sess. (I93I).

74 See appendix to dissent by Frankfurter, J., in Harris v. United States, 33I U.S. 145, I75 (r947), for list of relevant Supreme Court decisions. 
how attempts to impose minority morals may lead to an invasion of the civil liberties of the majority. But even under rigidly-enforced laws the continuation of sex activities would still be infinitely easier than was the manufacture and transportation of liquor, and such a policy might well lead to an increase in organized prostitution.

Those convinced of the impracticability of more rigorous enforcement may nevertheless wish to retain the statutes in their present state because of a belief that the law, as an integral part of the mores-forming social apparatus, ${ }^{75} \mathrm{em}$ bodies the ideal morality toward which people are or should be striving. ${ }^{76}$ Some laws are not intended to be enforced but simply represent an expression of public policy, it is said. Proponents of this view point to the analogy of laws against discrimination advocated in the face of contrary popular attitudes, or they may assert that the state should possess a ready tool for the early segregation of dangerous "real" sex criminals. Convinced of the impossibility of satisfactory amendment or repeal, they may even point to the enforcement figures to argue that these laws will slowly fall into desuetude and thus approach the limit of complete annulment. ${ }^{77}$

But the maintenance of a law not sought to be enforced adds an impetus to the perpetration of blackmail, ${ }^{78}$ and may lead to popular disrepect for all law. An unenforced statute will contribute little to the formation of popular mores, and the discrimination analogy is fallacious because it ignores that such statutes seek to undo the effect of environment, not instinct. The theory that these laws are convenient tools for the preventive arrest of potential sex slayers is based on the erroneous assumption that a desire for nonmarital intercourse implies sadism, and, besides affording no guaranty against prosecution of harm-

${ }^{75}$ Hall, Prolegomena to a Science of Criminal Law, 89 U. of Pa. L. Rev. 549 (I94I).

${ }^{76}$ "The test of a criminal law is not its correlation with actual behavior, but its correspondence to behavior ideals and its efficiency in promoting those ideals." Schwartz, Review of the Kinsey Report, 96 U. of Pa. L. Rev. 9I4, 9I5 (I948); see also Mead, An Anthropologist Looks at the Report, in Problems of Sexual Behavior 58 (I948). The conflict between attitude ideals and practical necessities, according to one view, results in the establishment of $s u b$ rosa institutions: Arnold, The Folklore of Capitalism 207-9 (r937) (referring to anti-vice and antitrust laws). Surprisingly, even psychoanalysts can see a justification for the laws. "Culture has to call up every possible reinforcement in order to erect barriers against the aggressive instincts of men and hold their manifestations in check by reaction-formations in men's minds. Hence ... the restriction on sexual life. ..." Freud, Civilization and its Discontents, 86-87 (I930). For an excellent recent analysis of the function of the criminal law as a purgative for the social aggressions of the unpunished population, see Reiwald, Die Gesellschaft und Thre Verbrecher (Zürich, 1948).

${ }_{77}$ An analogy to the enforcement of American "blue laws" might be suggested, but I5,000 "other sex offense" prosecutions a year belie the notion of desuetude at least for the victims. Professor Harper, however, considers legislation by desuetude the only immediately practicable method for limiting the effects of sex "book law." Op. cit. supra note 6 .

${ }^{78}$ How the threat of prosecution was sought to be turned into large amounts of cash by public law-enforcement officials is shown in Attorney General v. Pelletier, 240 Mass. 264, 327$30,1_{34}$ N.E. 407, 427-29 (1922) (\$50,000 sought for stay of prosecution for adultery and lewd and lascivious ccohabitation); Attorney General v. Tufts, 239 Mass. 458, 50I-7, 5II-I6, I32 N.E. 322, 33I-34,336-38 (1921) (\$100,000 paid for stay of prosecution of movie magnates for visiting house of ill fame). 
less persons, indicates an unsophisticated approach to the serious problem of the true pervert. ${ }^{79}$ Thus some conclude that the concerted effort of home, school, and church, supplemented if need be by various forms of social ostracism, suffices to inculcate individual restraint in private sex relations, ${ }^{80}$ and that the function of law in this sphere should be confined to public outrages or nonconsensual private wrongs. ${ }^{81}$

All major civilized countries except a few American states ${ }^{82}$ apparently reflect such an attitude with regard to fornication, since not one of them makes this act a crime. In England, repeated attempts to make even adultery an offense punishable by the secular courts failed long ago. ${ }^{83}$ The modern code of the U.S.S.R. also does not consider adultery a criminal act, although the French code, unlike the German, discriminates between the sexes in establishing and punishing this act as an offense. ${ }^{84}$ The behavior content of sodomy where it is established as a crime is differently defined, depending on the practicability of enforcement and on the contemplated social harm of a particular act. Thus "unnatural acts" between husband and wife, masturbation (mutual or single), inter-female homosexuality, and necrophilia may be excluded from the definition, which may be so restricted as to allow prosecution only where such acts constitute a "public outrage."85

79 In seeking to define a "true pervert," the law faces a problem not yet solved by psychiatry. For a discussion of difficulties encountered in defining a related condition, psychopathic personality, consult Arieff and Rotman, Psychopathic Personality-Some Social and Psychiatric Aspects, 39 J. Crim. L. 158 (I948).

${ }^{80}$ As to the sufficiency of these factors in the absence of formal legal sanctions, see Margold, Sex Freedom and Social Control (r926), but compare Malinowski, Crime and Custom in Savage Society (I932) as to the alleged absence of formal law in primitive societies. That Kinsey himself does not place much faith in the law as a restraint on nonmarital intercourse is inferable from table 92 , Kinsey, op. cit. supra note $x$, at $3^{64}$, where law is not even listed as one of the deterrent attitude factors.

${ }^{81}$ The attitude is not novel. Application of such a law would "subject behavior perhaps at worst merely imprudent, to critical investigation; and leave the actions and behavior of innocent persons exposed to idle conjecture, to unwarrantable construction and impertinent curiosity"; whereby "... the indecency of the inquiries would produce more harm than prosecutions would do good." Kinsey [sic], C. J., in Smith v. Minor, I N.J.L. I6, 22 (1790). Similar views have been approved by Burling, Review of the Kinsey Report, 23 N.Y.U.L.Q. Rev. 540, 543 (1948); Llewellyn, The Limits of Sexual Law, in About the Kinsey Report II3, I23 (ed. Geddes and Currie, I948); Mannheim, Criminal Justice and Social Reconstruction 5 (I946); Million, Limitations on the Enforcement of Legal Sanctions, 28 Geo. L. J. 464 (1940); Shumaker, The Enforceability of Sumptuary Laws, $32 \mathrm{~L}$. Notes 25,26 (I928); Pound, The Limits of Effective Legal Action, 27 Int. J. of Ethics I5० (IgI7); Bentham, Principles of Legislation, in Theory of Legislation 6I-62 (6th ed. I89o).

${ }^{82}$ See Table I supra, for the population percentages involved.

${ }_{83} 3$ Stephen, History of Criminal Law of England 318 (r883). For an interesting account of the current status of sex law in England (but pre-Baxter v. Baxter), consult East, Sexual Offenders-A British View, 55 Yale L.J. 527 (1946).

${ }^{84}$ Code Penal (ed. Dalloz I938) $\$ \S 336-39$ (the husband can only be prosecuted for keeping a concubine within the home); Strafgesetzbuch (Kohlrausch, I930) $\$ 172$ (dissolution of marriage is a prerequisite to permissive prosecution).

${ }^{85}$ Mittermaier, Verbrechen und Vergehen wider die Sittlichkeit: Widernatürliche Unzucht, 4 Vergleichende Darstellung des Deutschen und Ausländischen Strafrechts 147 (Ig06). 
Commentators to the German Penal Code have questioned the desirability of punishing sodomy where it consists of the voluntary acts of adults. It is argued that the admittedly greater clamor for the suppression of this less widely-distributed behavior is not based on rational considerations, because the risk of a lower birth rate and disease is no more serious than that attending other lawful types of nonmarital relations. ${ }^{86}$ An alleged connection between psychic disturbances conducive to sodomy and those resulting in major sex crimes is properly a subject of medical investigation rather than of penal sanctions. In recent years some American states have passed statutes authorizing medical examination of suspected "sexual psychopaths" and their detention in nonpenal state institutions until they are no longer socially dangerous. 87 These states realize that the selective enforcement of sodomy or other sex statutes, while it may temporarily segregate the dangerous offender, does not insure his cure or permanent harmlessness, which is the only effective social protection. If such statutory provisions were to be generally adopted, the desirability of retaining anti-sodomy statutes could be reviewed on its merits, subject to the same considerations that apply to laws against adultery and fornication.

Modern provisions in the German and Soviet codes tend to insure the complete "voluntariness" of permissible sexual relations, and provide heavier penalties where non-permissible acts do not reflect the free will of the participating parties. ${ }^{88}$ Sections in these codes forbid the securing of sexual gratification by virtue of an advantageous social or economic position. Many American statutes already provide special penalties for persons in charge of prisoners, patients, pupils, etc. who subvert their positions of trust in this manner. It may be desirable to expand these laws to cover business executives and government officials who might be "bribed" by offers of gratification. Such an extension could, however, multiply opportunities for extortion unless protected by rigorous procedural requirements.

Any systematic revision of current sex laws should thus not be confined to the amendment or repeal of statutes against consensual private sex acts. The Kinsey data necessitate reconsideration of the validity of the rationale underlying statutory rape, seduction, and divorce laws. The fiction that a girl of sixteen, whose deportment belies her true age to the objective observer, has no

\footnotetext{
${ }^{86}$ Hirschfeld, § I75 des Reichsstrafgesetzbuchs-Die Homosexuelle Frage im Urteile der Zeitgenossen ( (I898). See also citations in Mittermaier, op. cit. supra note 85. Comparative law and remedial aspects, with emphasis on homosexuality, are discussed in Mannheim, Criminal Justice and Social Reconstruction, C. 4 (I946).

${ }^{87}$ The Legal Disposition of the Sexual Psychopath, 96 U. of Pa. L. Rev. 872 (I948). See also the approved draft of the Chicago Bar Association for "an act to provide for the commitment, care, custody, treatment, and discharge of sexually dangerous persons" (unpublished committee draft, dated Oct. 26, I948).

${ }^{88}$ Strafgesetzbuch $\delta \S \mathrm{I74}, x 75 \mathrm{a}(\mathrm{x})-(3)$. Nazi amendments have here been retained by the military government, I Statutory Criminal Law of Germany, II3-I4 (I946). Ugolovnyi Kodeks RSFSR $\$ \S$ r 54, I54a (the latter amendment, added in 1934 , prohibits homosexuality between males, and imposes heavy penalties for taking advantage of a superior bargaining position) (1935). See also Mannheim, op. cit. supra note 86.
} 
legally-recognizable "will" of her own creates greater mischief than that which it is designed to cure. Applicable heavy rape penalties often induce prosecutors as well as judges to circumvent the law by charging the offender with a minor misdemeanor instead. ${ }^{80}$ Seduction, which in reality is simply taking advantage of a promise subsequently not kept, perhaps should not be punishable as a crime, since a civil remedy transcending damages for breach of contract is too readily available in most states. ${ }^{90}$ Whether a single act of adultery, easily faked and often condoned, should under all circumstances be a good ground for divorce is a question which legislatures might well ponder. ${ }^{91}$ Laws relating to white-slave traffic, abortion, and the dissemination of contraceptive information also need to be modified to support a consistent approach to statutory prohibition of $\sin .^{92}$

Even though the wide circulation of the Kinsey Report will have helped crystallize broad social support for such a program, a proposal for outright repeal of laws punishing private voluntary sex acts would encounter strong opposition. The shock would be somewhat cushioned by simultaneous proposals to enact some of the new laws discussed above. Other effective methods of repeal would arouse much less organized antagonism. Thus, a stringent technical approach to the rules of evidence relating to these offenses, such as prohibition of admission of testimony of the volunteer partner for all purposes, would not produce a public outcry, but nonetheless would effectively cripple the statutes. Provisions that the offenses must in all cases be "open and notorious," or subject to a similar requirement not lending itself too readily to prompt judicial misinterpretation of "legislative intent," would accomplish a similar result. If strict enforcement of all state sex laws were decreed for a short time only, pressure for legislative repeal would become irrepressible. ${ }^{93}$

89 This practice is not confined to rape cases. In the municipal court of Chicago, for example, persons guilty of adultery or fornication under Illinois law are evidently charged with the lesser offense of disorderly conduct as a matter of course. Waters, The Use of Chicago's Disorderly Conduct Ordinance (unpublished thesis for the master's degree, School of Social Service Administration, University of Chicago I948). Significantly, the statistics of the Chicago Crime Commission do not show return of a single indictment for adultery during I947, although they do indicate that, in more serious sex offenses excluding rape and prostitution, only about onethird of the convicted offenders were sent to jail. Criminal Court Record for 1947 , Chicago Crime Commission (unpublished).

${ }^{90}$ Because of the ease in which a "promise to marry" can be feigned, abolition of the civil remedy for seduction of adult women has also been urged. Feinsinger, op. cit. supra note 48 .

"1 See Schwartz, Review of the Kinsey Report, 96 U. of Pa. I. Rev. 9I4, 917-I8 (I948).

${ }_{22}$ White-slavery laws should be confined to prostitution proper so as not to become convenient media for judicial morals legislation. If fewer abortions are wanted, logic and the Kinsey data would indicate the necessity for spreading contraceptive information, particularly to less sophisticated population groups. See, on this latter point, Contraceptives and the Law, 6 Univ. Chi. L. Rev. 260 (1939). On the overall problem see Russell, Why a Sexual Ethics is Necessary, in The Sex Problem of Modern Society (r93I).

${ }^{93}$ This method of "repeal" proved surprisingly effective with regard to certain "blue laws." Morford, Ancient Blue Laws Are Cobwebs in the Legal Attics of Many States, I4 St. Gov't. Iro (I94I). 
While direct repeal of the fornication statutes only might be successfully advocated, this legislative approach would perpetuate an illogical distinction between fornication and other voluntary sex offenses. Legislative recognition of a greater quantum of social objection to sodomy might at first confine repeal to provisions applicable to married couples, although ultimately this offense should not be treated differently than the others.

The thriving existence of civilized societies whose criminal laws do not punish voluntary private sexual relations between adults would dispose of ungrounded fears that morality will degenerate in the absence of such laws. The powerful checks of home, school, church, and social evaluation do not require as a supplement an unwieldy law enforcement apparatus. If the criminal law is to become or remain a respected tool in the maintenance of social order, its retention in a particular instance can only be justified by its reasonable correlation to the subsumed social facts. 